\title{
Exploring the versatility of gingiva-colored composite
}

This article was published in the following Dove Press journal:

Clinical, Cosmetic and Investigational Dentistry

I8 April 2016

Number of times this article has been viewed

\section{Amit A Paryag' \\ Reisha N Rafeek' \\ Melissa S Mankee ${ }^{2}$ \\ Jenai Lowe'}

'School of Dentistry, The University of the West Indies, Mount Hope,

${ }^{2}$ Tooth Haven Dental Studio, D'Abadie, Trinidad and Tobago
Correspondence: Reisha N Rafeek School of Dentistry, The University of the West Indies, Mount Hope, Trinidad and Tobago

Email reisha.rafeek@sta.uwi.edu

\begin{abstract}
Gingival recession has a diverse etiology. The consequences may include gingivitis, periodontitis, and hypersensitivity. Whereas the management can include surgical treatment options, sometimes a more conservative, yet still esthetic approach may be required. The use of gingiva-colored composites provides one such alternative and can be applied to varying presentations of the problem. While surgical treatment can be successful in re-creating favorable esthetic anatomy as well as achieving accurate tissue contour in cases when minor amounts of tissue are reconstructed, long-term results vary because of the vascularity and complexity of the interdental space. Factors such as cost, healing time, discomfort, and variable long-term results make surgery an unpopular choice. If tooth-colored restorative materials are utilized to restore cervical tooth exposure as a result of severe recession, the disproportionate appearance of the visible crown may give a dissatisfying result. Gingiva-colored composite provides dental practitioners with a versatile material that can be used to directly restore cervical defects caused by gingival recession, thus correcting the appearance of the gingival anatomy. It offers a treatment option that may increase patient satisfaction through the provision of a cost-effective, minimally invasive solution with highly esthetic results.
\end{abstract}

Keywords: gingiva composite, cervical restoration, esthetics

\section{Introduction}

Gingival recession has a diverse etiology and may result in exposure and secondary damage of exposed root surfaces. The consequences may include gingivitis, periodontitis, and hypersensitivity. With a prevalence ranging from $37.8 \%$ (in the $30-39$ age group) to $90.4 \%$ (the $80-90$ age group), it is a problem affecting all ages to varying degrees. Whereas the management can include surgical treatment options, sometimes a more conservative, yet still esthetic approach may be required. The use of gingival-colored composites provides one such alternative and can be applied to varying presentations of the problem. This paper seeks to outline the background to the problem and present some clinical scenarios where gingival-colored composite has been used to good effect in the management of lesions arising from gingival recession.

Gingival recession can be defined as the apical migration of gingival margin to the cementoenamel junction. Causes include periodontal disease, accumulations, inflammation, improper brushing and flossing habits, unstable occlusal relationships, and dominant roots. ${ }^{1}$ The occurrence may or may not be in conjunction with loss of attached tissue and may be associated with sensitivity because of the exposed dentin.

The data from the US National Survey show that $88 \%$ of seniors (age $\geq 65$ ) and $50 \%$ of adults (age 18-64) present with recession in one or more sites. As there is an increase you hereby accept the Terms. Non-commercial uses of the work are permitted without any further permission from Dove Medical Press Limited, provided the work is properly attributed. For you hereby accept the Terms. Non-commercial uses of the work are permitted without any further permission from Dove Medical Press
permission for commercial use of this work, please see paragraphs 4.2 and 5 of our Terms (https://www.dovepress.com/terms.php). 
in age, there is a progressive increase in frequency and extent of recession being observed. ${ }^{2}$ The prevalence of recession was $37.8 \%$ in the youngest age cohort (30-39 years), and in contrast, the oldest cohort, aged 80-90 years, had a prevalence of $90.4 \%$ (more than twice as high). ${ }^{3}$ Table 1 outlines the varied factors that can be associated with gingival recession.

Therefore, it can be seen that gingival recession is a common occurrence with a multifactorial etiology and is always associated with alveolar bone dehiscences. ${ }^{13}$ The amount of bone around the roots plays a role, and even around implants, it has been shown that the thicker the buccal bone, the thicker the crestal labial soft tissue thickness and vice versa. ${ }^{14}$

The consequences can include esthetic concerns, ${ }^{15}$ gingival bleeding and plaque retention, hypersensitivity, ${ }^{16}$ and caries. ${ }^{17}$ Table 2 outlines the factors that should be considered in managing gingival recession defects.

Interdisciplinary approaches are often required for restoration of esthetics and function of the periodontal supporting structures lost due to periodontal disease. ${ }^{23}$

Prosthetic approaches to reproduction of artificial gingival tissue include porcelain, acrylics (denture base material), silicone-based soft materials, or co-polyamide and composite resin, ${ }^{23}$ each with its associated merits, demerits, and specific indications. For example, a removable prosthesis can facilitate a larger volume of tissue replacement without disturbing other dental units while allowing proper cleaning, whereas for fixed restoration of soft tissue in the esthetic zone, gingiva-colored (pink) porcelain can help in

Table I Factors that can be associated with gingival recession

\begin{tabular}{|c|c|}
\hline Calculus & $\begin{array}{l}\text { Supragingival and subgingival calculus along with } \\
\text { inadequate oral hygiene is associated with gingival } \\
\text { reccession }{ }^{4}\end{array}$ \\
\hline Tooth brushing & $\begin{array}{l}\text { Using a hard toothbrush is associated with } \\
\text { recession }^{5}\end{array}$ \\
\hline $\begin{array}{l}\text { High frenal } \\
\text { attachment }\end{array}$ & Pulls on marginal gingiva impeding plaque removal ${ }^{6}$ \\
\hline Tooth position & $\begin{array}{l}\text { Localized gingival recession around teeth erupting } \\
\text { close to mucogingival line }{ }^{7}\end{array}$ \\
\hline $\begin{array}{l}\text { Orthodontic } \\
\text { tooth movement }\end{array}$ & $\begin{array}{l}\text { Excessive proclination of incisors and arch } \\
\text { associated with greater risk of recession }{ }^{8}\end{array}$ \\
\hline $\begin{array}{l}\text { Improperly } \\
\text { designed partial } \\
\text { dentures }\end{array}$ & $\begin{array}{l}\text { Designs which cause plaque retention and } \\
\text { improper denture hygiene may promote recession? }\end{array}$ \\
\hline Smoking & $\begin{array}{l}\text { Recession is more common in smokers than } \\
\text { nonsmokers, often seen bucccally on maxillary } \\
\text { molars and premolars and mandibular incisors }{ }^{10}\end{array}$ \\
\hline Restorations & $\begin{array}{l}\text { Improper restoration contour, overhanging } \\
\text { restorations, and subgingival restorations can lead } \\
\text { to plaque accumulation and recession" }\end{array}$ \\
\hline Chemicals & $\begin{array}{l}\text { Topical cocaine use is associated with gingival } \\
\text { ulcerations and erosions }\end{array}$ \\
\hline
\end{tabular}

Table 2 Factors that should be considered in managing gingival recession

\begin{tabular}{|c|c|}
\hline $\begin{array}{l}\text { Restorations, crowns, } \\
\text { and veneers }\end{array}$ & $\begin{array}{l}\text { Changing crown contour, eg, widening to } \\
\text { camouflage exposed root }\end{array}$ \\
\hline $\begin{array}{l}\text { Construction of gingival } \\
\text { mask }\end{array}$ & $\begin{array}{l}\text { Silicone flexible gingival veneer or mask to } \\
\text { cover black triangles }\end{array}$ \\
\hline Root conditioning & $\begin{array}{l}\text { Tetracycline } \mathrm{HCl} \text { or citric acid can be applied } \\
\text { to roots prior to soft tissue grafting }\end{array}$ \\
\hline & and so reduce recession \\
\hline root coverage & $\begin{array}{l}\text { Grafts free epithilialized }{ }^{18} \text { or subepithelial } \\
\text { connective tissue }^{19} \\
\text { Flap - semilunar }{ }^{20} \text { or coronally advanced }{ }^{21} \\
\text { Guided tissue regeneration }{ }^{22}\end{array}$ \\
\hline
\end{tabular}

Abbreviation: $\mathrm{HCl}$, hydrochloric acid.

re-creating natural tooth proportions and provide a realistic alternative to surgery. ${ }^{23}$

While surgical treatment can be successful in re-creating favorable esthetic anatomy as well as achieving accurate tissue contour in cases when minor amounts of tissue are reconstructed, long-term results vary because of the vascularity and complexity of the interdental space. ${ }^{24}$ Factors such as surgical costs, healing time, discomfort, and varying long-term results make this choice unpopular. ${ }^{24}$

In order to protect the marginal periodontal tissues, prevent further tooth structure loss, reduce hypersensitivity, and improve esthetics, it is advocated that lesions with a depth of $0.5 \mathrm{~mm}$ be treated restoratively. ${ }^{25}$

Choice of restorative materials for these lesions includes both glass ionomer cements (GICs) and composite resins. ${ }^{26,27}$ However, GICs prove to have a more versatile clinical applications in the case of non-carious cervical lesions. ${ }^{28}$ GICs have a similar thermal expansion coefficient to that of tooth structure. ${ }^{26}$ The material also exhibits the ability to bond successfully with enamel and dentine as well as long-term fluoride release and favorable biocompatible properties. ${ }^{29}$

GICs in combination with surgical periodontal procedures such as coronally positioned flaps ${ }^{30}$ and connective tissue grafts ${ }^{31}$ have shown great promise as a management strategy for noncarious cervical lesions. Similar results have been obtained with microfilled resin composites and coronally positioned flaps. ${ }^{32}$

If tooth-colored restorative materials are utilized to restore cervical tooth exposure as a result of severe recession, the disproportionate appearance of the visible crown may give a dissatisfying result. Gingival-colored composites in conjunction with the utilization of tooth-colored restorative material allow for a minimally invasive adhesive restorative technique. ${ }^{33}$ The use of pink composite resin as an artificial gingival tissue was first described by Zalkind and Hochman in the management of a cervical defect. ${ }^{34}$ 


\section{Case summaries}

The patients in the following cases were seen by the first author in practice and written consent was given by the patients for pictures and demographics to be used for research, publication and teaching as long as anonymity was maintained. Ethical approval was not sought as treatment provided was part of routine care offered in a private practice setting. The following cases outline the use of gingiva-colored composite in varying clinical scenarios.

The composite used in the restoration of these cases was Amaris Gingiva (VOCO America, Inc., Indian Land, SC, USA), a branch of the German company VOCO GmbH, Germany. It is a methacrylate-based composite using Bisphenol - A - glycidyl dimethacrylate (BIS GMA), Urethane dimethacrylate (UDMA), and Tetraethyleneglycol dimethacrylate (TEGDMA) as matrix monomers. There are three opaquer shades available - white, light, and dark. The mixing of these in various amounts, and the combination of a base shade called NATURE, allows customization of the gingiva shade for any patient.

Natural pigmentation of gingiva varies between individuals and populations. The three shades of opaquer in Amaris gingiva enable the operator to blend the shades to produce a color that closely matches the patient's gingiva. Alternatively, the opaquer can be applied directly to the exposed root surface in a pattern mimicking the pigmentation seen on the patient's gingiva, thus enhancing the esthetic result.

The versatility of the material enables it to be used in defects of varying sizes and depths as illustrated in the cases presented. Case 1 shows the restoration of a defect of depth $>0.5 \mathrm{~mm}$. Case 2 shows the restoration of a defect of similar recession but not as deep into the tooth structure. In both cases, the material allows for restorations which are esthetic and durable.

Cases 3 and 4 illustrate the ability of the material to be used in recession defects of varying severity. Whereas the defects in Case 3 are not $>2 \mathrm{~mm}$, Case 4 shows restoration of three defects between 4 and $5 \mathrm{~mm}$. The cases also demonstrate the gingiva-colored composite being used in conjunction with tooth-colored composite as in Cases 2 and 3 and also with dentures in order to maximize esthetics.

\section{Case I}

A 35-year-old female patient presented with mild sensitivity in the left maxillary region. After being presented with options for management, the patient elected to have gingivacolored restorations placed. Figure 1 shows the lesions prior to placement. Figure 2 shows the lesions after restoration.

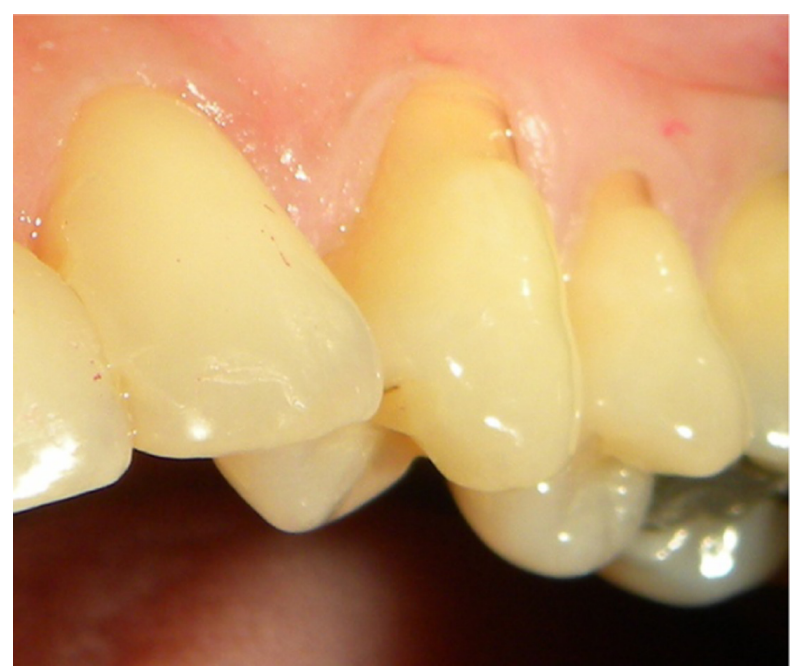

Figure I Class $\mathrm{V}$ lesions in cervical region of upper left premolars $>0.5 \mathrm{~mm}$ depth prior to placement.

\section{Case 2}

A 60-year-old female patient presented for routine dental cleaning. During treatment, recession defects were seen on the lower right premolars (Figure 3). The patient opted to have the defects restored using gingival-colored composites. For tooth \#45 (lower right second premolar), gingival-colored composite material and tooth-colored composite were used to restore a defect of depth $>0.5 \mathrm{~mm}$. However, tooth \#44, with a defect $<0.5 \mathrm{~mm}$, was restored using gingival-colored restorative material only (Figure 4).

\section{Case 3}

A 65-year-old female patient presented for removal of a defective Gold Splice closing a mesial diastema as seen in

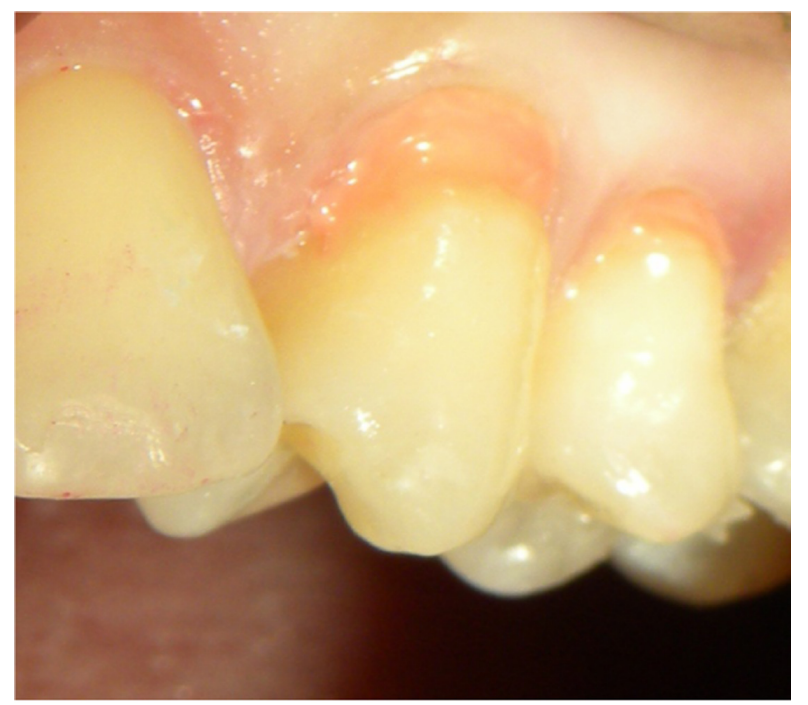

Figure 2 Class $\vee$ lesions in cervical region of upper left premolars restored with gingiva-colored composite. Photo was taken immediately on placement. 


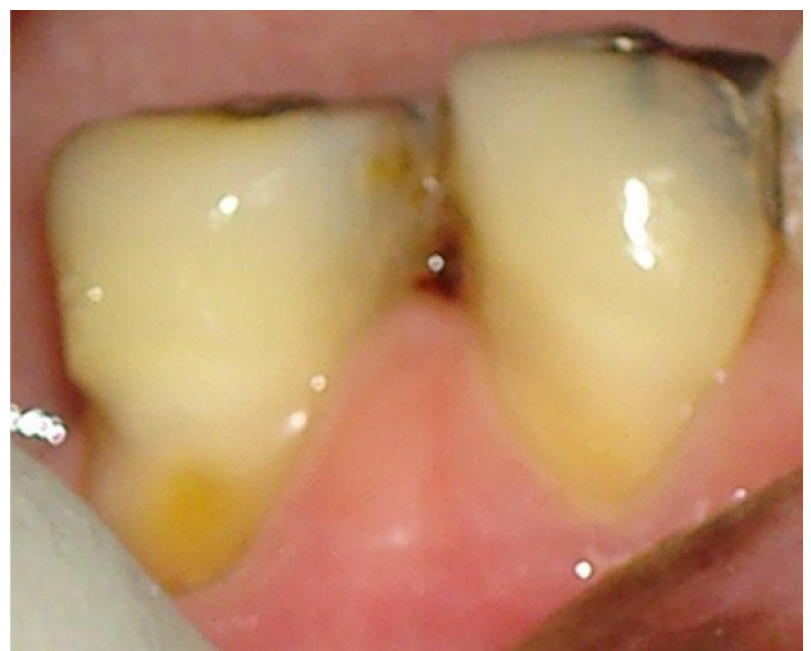

Figure 3 Class $V$ lesions in cervical region of lower right premolars $>0.5 \mathrm{~mm}$ depth involving loss of coronal structure as well.

Figure 5. As part of the treatment to provide better esthetics and improve the mesial distal contour and emergence profile of the central incisors, gingival-colored restorative material was used to restore the cervical lesions, and tooth-colored composites were used to restore the diastema and reshape the coronal aspect of the teeth (Figure 6).

\section{Case 4}

A 55-year-old man presented for replacement of missing units in the maxilla and mandible. Cobalt chrome dentures were provided for the patient. A clear clasp was used to improve esthetics around the upper left canine (Figure 7). The patient then decided to have the cervical lesions on the upper left canine and premolars restored with gingival-colored composite to try and achieve maximum esthetics (Figure 8). The case

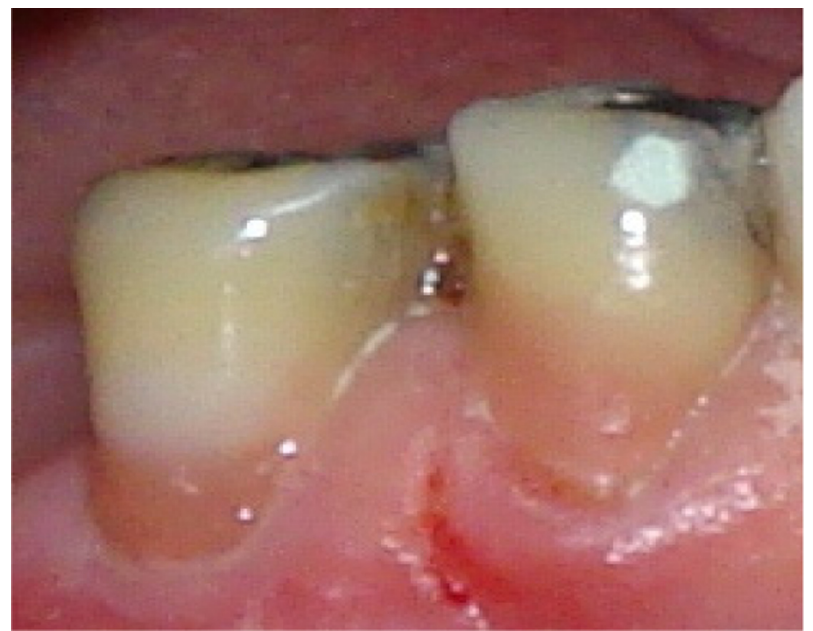

Figure 4 Class $V$ lesions in cervical region of lower right premolars restored with gingiva-colored composite and tooth-colored composite shown after 2 years of follow-up.

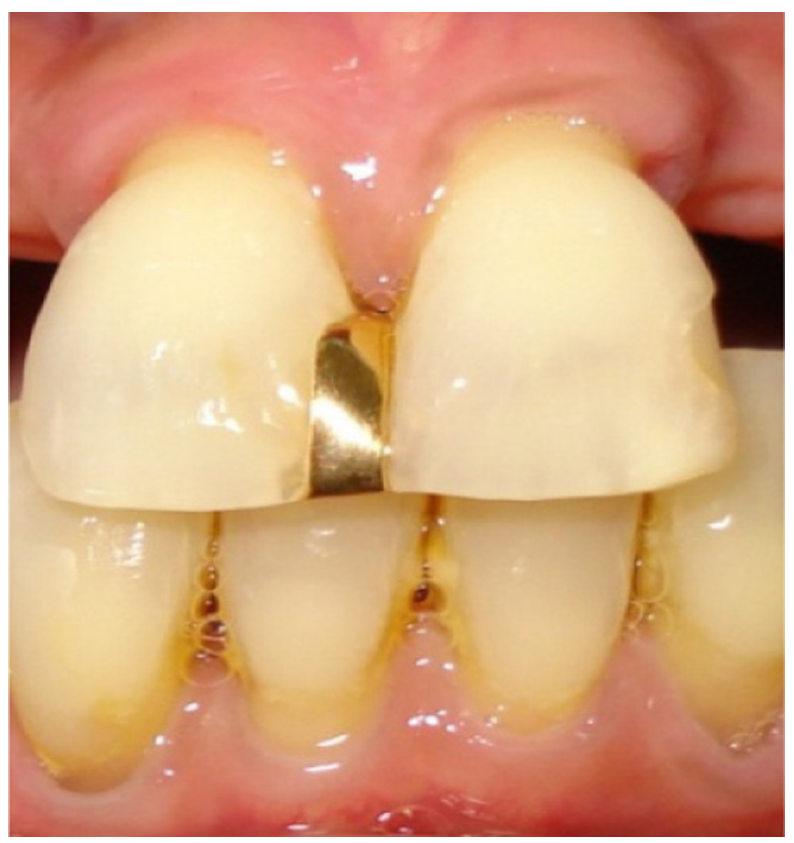

Figure 5 Class $\vee$ lesions in cervical region of upper central incisors $>0.5 \mathrm{~mm}$ depth. Defective Gold Splice was closing the mesial diastema.

demonstrates the versatility of the gingiva-colored composite being used with dentures and esthetic clasps.

\section{Discussion}

Comprehensive knowledge of facial esthetics, tooth morphology, available restoration techniques, and commu-

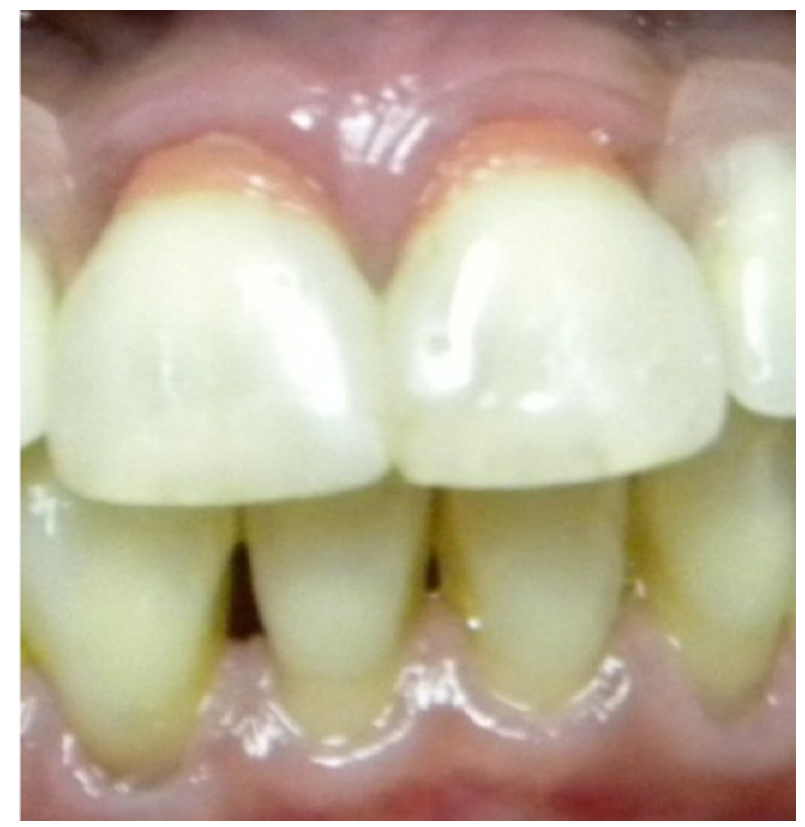

Figure 6 Class $V$ lesions in cervical region of upper central incisors restored with gingiva-colored composite. Tooth-colored composites were used to restore the diastema and reshape the coronal aspect of the teeth helping to re-create emergence profile for wider crowns to enhance appearance of anterior teeth, shown after 6 months of follow-up. 


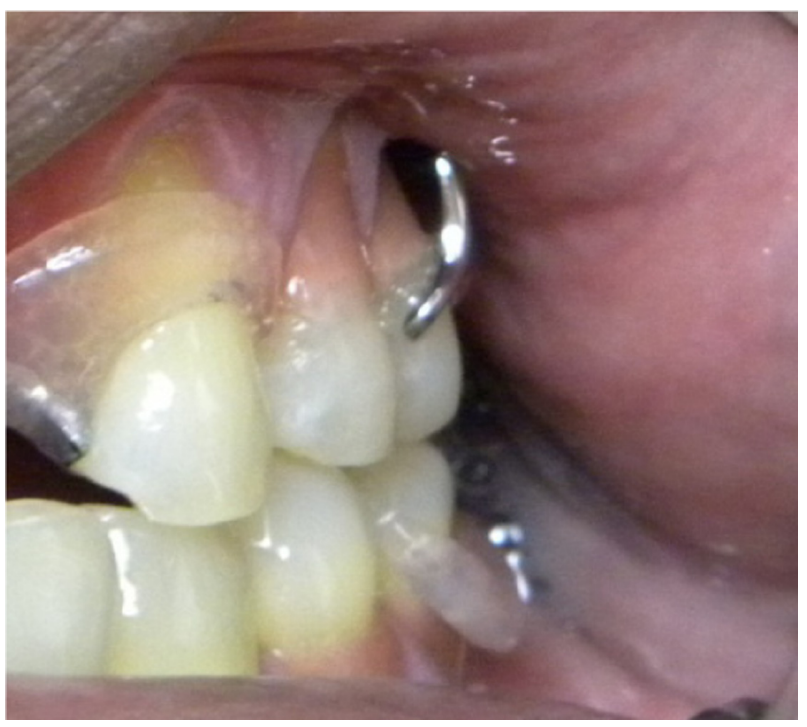

Figure 7 Class $V$ lesions in cervical region of upper left premolars and canine $>0.5 \mathrm{~mm}$ depth.

nication skills, combined with an understanding of smile components, teeth, gingival tissues, and lips, is integral in esthetic dentistry. ${ }^{23}$ Ensuring that the correct width-length ratio is established for maxillary anterior teeth ${ }^{35,36}$ helps to determine ideal gingival levels which generally run parallel to the upper lip and are bilaterally symmetrical. Other characteristics of the tissue relationships have been well documented. . $^{37,38}$

Resin-based composites and glass ionomer cements have been proven to produce positive results in treating class $\mathrm{V}$

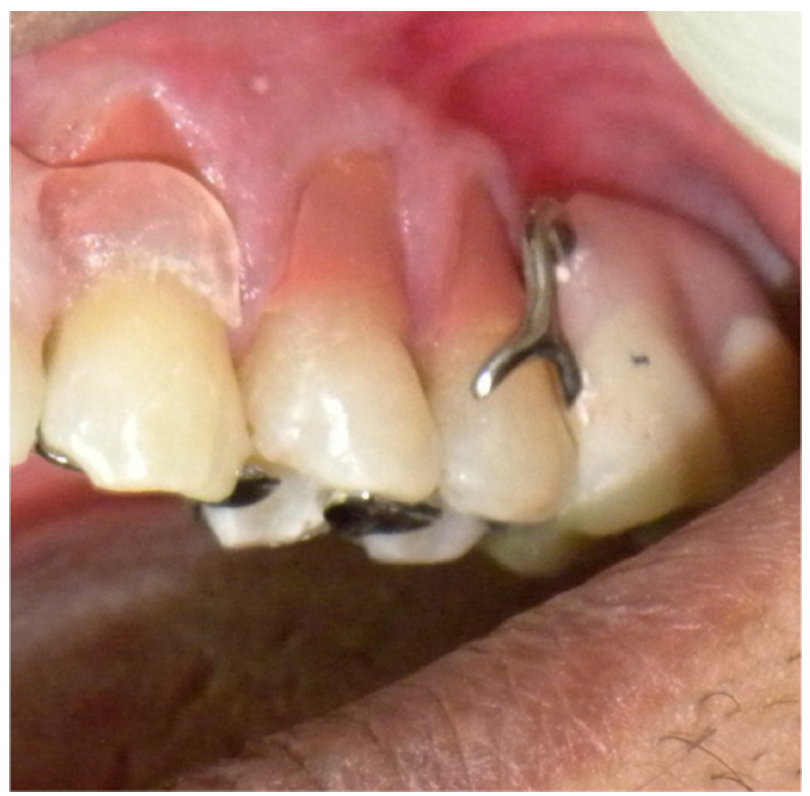

Figure 8 Class $V$ lesions in cervical region of upper left canine and premolars $>0.5 \mathrm{~mm}$ restored with gingival-colored composite to enhance esthetics in region and below clear denture clasp on canine shown immediately after placement. lesions and associated gingival recession. ${ }^{26-28,39}$ Should further recession take place, additions of composite could be made to cover the resulting defect, although in such a case, serious consideration would need to be given to why the recession was progressing. Careful finishing of the margin of the gingival composite would be necessary to ensure that plaque trapping around the restoration did not contribute to this situation. It is confirmed clinically that composites have no adverse effects on gingival health, as well as that there is reduced inflammatory response to properly contoured and finished/polished composite resins in comparison to carious lesions that remain untreated. ${ }^{39}$ To date, no studies have been done comparing the shelf life of gingival-colored restorative material with regular composites or GIC, and this would be an area for further investigation.

The application of tooth-colored composite and GIC restorative materials to teeth presenting with gingival recession often results in the restored tooth or teeth appearing overly long and subsequently unesthetic. ${ }^{33,40}$ In light of this clinical observation, manufacturers have sought to create restorative materials to better exhibit the esthetic qualities of the gingiva in order to address this need. In restoring defects caused by gingival recession, a gingival-colored composite would provide an option for bonding a simple restoration to the exposed root as with any other class $\mathrm{V}$ restoration as is seen in Cases 1-4. In addition to the esthetic value of the gingival-colored restorative materials, their use also enables the application of minimally invasive procedures as an option to restore the effects of gingival recession as in Case $1 .{ }^{40}$ In combination with tooth-colored restorations as seen in Cases 2 and 3, this could produce the desired esthetic result.

A false or pseudo gingival sulcus can be created coincident with the previous free gingival margin, thereby improving soft tissue esthetics with adhesive materials. ${ }^{41}$ In cases where the patient may be wearing dentures, an attempt can be made to match the height of this sulcus to the height of the gingival margin on the denture improving the chance of an esthetic match as seen in Cases 3 and 4.

The gingiva-colored composite restoration would allow the patient an opportunity to see the esthetic result of having the gingiva replaced in this region and the effect with the altered appearance of the front teeth as a whole. This treatment option provides a practical clinical solution for patients that is economically viable and esthetically pleasing ${ }^{40}$ allowing the patients to visualize the final result and even possibly better inform their decision to undergo surgery. 


\section{Conclusion}

Cervical lesions resulting from gingival recession often require periodontal surgical procedures to correct the effects of gingival recession and consequent esthetic defects. This is often associated with cost, recovery, and pain to the patient. Gingival-colored composite provides dental practitioners with a versatile material that can be used to directly restore cervical defects caused by gingival recession, thus correcting the appearance of the gingival anatomy. It offers a treatment option that may increase patient satisfaction through the provision of a cost-effective, minimally invasive solution with highly esthetic results.

\section{Disclosure}

The authors report no conflicts of interest in this work.

\section{References}

1. Pradeep K, Rajababu P, Satyanarayana D, Sagar V. Gingival recession: review and strategies in treatment of recession. Case Rep Dent. 2012;2012(2):563421

2. Miller AJ, Brunelle JA, Carlos JP, Brown LJ, Löe H. Oral health of United States adults. The national survey of oral health in U.S. employed adults and seniors: (1985-1986). NIH publication no. 87-2868.

3. Albandar JM, Kingman A. Gingival recession, gingival bleeding, and dental calculus in adults 30 years of age and older in the United States, 1988-1994. J Periodontol. 1999;70:30-43.

4. Van Palenstein Helderman WH, Lembariti BS, Van Der Weijden GA, Van't Hof MA. Gingival recession and its association with calculus in subjects deprived of prophylactic dental care. J Clin Periodontol. 1998;25:106-111.

5. Khocht A, Simon G, Person P, Denepitiya JL. Gingival recession in relation to history of hard toothbrush use. J Periodontol. 1993;64:900-905.

6. Trott JR, Love B. An analysis of localized gingival recession in 766 Winnipeg High School students. Dent Pract Dent Rec. 1966;16:209-213.

7. Zachrisson BU. Orthodontics and periodontics. In: Lindhe J, editor. Clinical Periodontology and Implant Dentistry. 3rd ed. Copenhagen, Denmark: Munksgaard; 1998:741-793.

8. Årtun J, Krogstad O. Periodontal status of mandibular incisors following excessive proclination: a study in adults with surgically treated mandibular prognathism. Am J Orthod Dentofacial Orthop. 1987;91:225-232.

9. Wright PS, Hellyer PH. Gingival recession related to removable partial dentures in older patients. J Prosthet Dent. 1995;74:602-607.

10. Gunsolley JC, Quinn SM, Tew J, Gooss CM, Brooks CN, Schenkein HA. The effect of smoking on individuals with minimal periodontal destruction. J Periodontol. 1998;69:165-170.

11. Parma-Benfenati S, Fugazzato PA, Ruben MP. The effect of restorative margins on post-surgical development and nature of periodontium. Int J Periodontics Restorative Dent. 1985;5:31-51.

12. Quart AM, Butkus Small C, Klein RS. The cocaine connection. Users imperil their gingiva. J Am Dent Assoc. 1991;122:85-87.

13. Borzabadi-Farahani A. A review of the oral health-related evidence that supports the orthodontic treatment need indices. Prog Orthod. 2012;13:314-325.

14. Le BT, Borzabadi-Farahani A. Labial bone thickness in area of anterior maxillary implants associated with crestal labial soft tissue thickness. Implant Dent. 2012;21:406-410.

15. Greene PR. The flexible gingival mask: an aesthetic solution in periodontal practice. Br Dent J. 1998;184:536-540.
16. Brannstrom M, Astrom A. The hydrodynamics of the dentine; its possible relationship to dentinal pain. Int Dent J. 1972;22:219-227.

17. Reiker J, Van Der Velden U, Barendregt DS, Loos BG. A cross-sectional study into the prevalence of root caries in periodontal maintenance patients. J Clin Periodontol. 1999;26:26-32.

18. Sullivan HC, Atkins JH. Free autogenous gingival grafts. I. Principles of successful grafting. Periodontics. 1968;6:121-129.

19. Langer B, Langer L. Subepithelial connective tissue graft technique for root coverage. J Periodontol. 1985;56:715-720.

20. Tarnow DP. Semilunar coronally repositioned flap. J Clin Periodontol. 1986;13:182-185.

21. Sumner CF III. Surgical repair of recession on the maxillary cuspid: incisally repositioning the gingival tissues. J Periodontol. 1969;40:119-121

22. Pini Prato G, Tinti C, Vincenzi G, Magnani C, Cortellini P, Clauser C. Guided tissue regeneration versus mucogingival surgery in the treatment of human buccal gingival recession. J Periodontol. 1992;63: 919-928.

23. Wahbi MA, Al Sharief HS, Tayeb H, Bokhari A. Minimally invasive use of coloured composite resin in aesthetic restoration of periodontally involved teeth: case report. Saudi Dent J. 2013;25: 83-89.

24. Babu KB, Madhu Babu DS, Dodani K, Sekhar L, Reddy NR. Reconstruction of the interdental papillae using an interdisciplinary approach following orthodontic treatment: a case report. Int J Contemp Dent. 2012;2:2

25. Hand JS, Hunt RJ, Reinhardt JW. The prevalence and treatment implications of cervical abrasion in the elderly. Gerodontics. 1986;2:167-170.

26. Özgünaltay G, Önen A. Three-year clinical evaluation of a resin modified glass-ionomer cement and a composite resin in non-carious class $\mathrm{V}$ lesions. J Oral Rehabil. 2002;29:1037-1041.

27. Powell LV, Gordon GE, Johnson GH. Clinical evaluation of direct esthetic restorations in cervical abrasion/erosion lesions: one-year results. Quintessence Int. 1991;22:687-697.

28. Powell LV, Johnson GH, Gordon GE. Factors associated with clinical success of cervical abrasion/erosion restorations. Oper Dent. $1995 ; 20: 713$.

29. Nicholson JW, Czarnecka B. The biocompatibility of resinmodified glass-ionomer cements for dentistry. Dent Mater. 2008;24: $1702-1708$.

30. Santamaria MP, Suaid FF, Casati MZ, Nociti FH, Sallum AW, Sallum EA. Coronally positioned flap plus resin-modified glass ionomer restoration for the treatment of gingival recession associated with non-carious cervical lesions: a randomized controlled clinical trial. J Periodontol. 2008;79:621-628

31. Santamaria MP, Ambrosano GMB, Casati MZ, Nociti Júnior FH, Sallum AW, Sallum EA. Connective tissue graft plus resin-modified glass ionomer restoration for the treatment of gingival recession associated with non-carious cervical lesion: a randomized-controlled clinical trial. J Clin Periodontol. 2009;36:791-798

32. Lucchesi JA, Santos VR, Amaral CM, Peruzzo DC, Duarte PM. Coronally positioned flap for treatment of restored root surfaces: a 6-month clinical evaluation. J Periodontol. 2007;78:615-623.

33. Günay H, Geurtsen W, Lührs AK. Conservative treatment of periodontal recessions with class $\mathrm{V}$ defects using gingiva-shaded composite - a systematic treatment concept. Dent Update. 2011;38(2):124-126, $128-130,132$

34. Zalkind M, Hochman N. Alternative method of conservative esthetic treatment for gingival recession. J Prosthet Dent. 1997;77:561-563.

35. Marus R. Treatment planning and smile design using composite resin. Pract Proced Aesthet Dent. 2006;18:235-241.

36. Wolfart S, Thormann H, Freitag S, Kern M. Assessment of dental appearance following changes in incisor proportions. Eur J Oral Sci. 2005;113:159-165.

37. Feigenbaum NL. Aspects of aesthetic smile design. Pract Periodontics Aesthet Dent. 1991;3:9-13. 
38. Magne P, Belser UC. Novel porcelain laminate preparation approach driven by a diagnostic mock-up. J Esthet Restor Dent. 2004; 16:7-16.

39. Blank LW, Caffesse RG, Charbeneau GT. The gingival response to well-finished composite resin restorations. J Prosthet Dent. 1979;42:626-632.
40. van Dijken JW, Sjöström S, Wing K. The effect of different types of composite resin fillings on marginal gingiva. J Clin Periodontol. 1987; 14:185-189.

41. Alani A, Maglad A, Nohl F. The prosthetic management of gingival aesthetics. Br Dent J. 2011;210:63-69.

\section{Publish your work in this journal}

Clinical, Cosmetic and Investigational Dentistry is an international, peer-reviewed, open access, online journal focusing on the latest clinical and experimental research in dentistry with specific emphasis on cosmetic interventions. Innovative developments in dental materials, techniques and devices that improve outcomes and patient satisfac- tion and preference will be highlighted. The manuscript management system is completely online and includes a very quick and fair peerreview system, which is all easy to use. Visit http://www.dovepress. com/testimonials.php to read real quotes from published authors.

Submit your manuscript here: http://www.dovepress.com/clinical-cosmetic-and-investigational-dentistry-journal 